\title{
Pelindian Bijih Nikel Laterit Kadar Rendah Menggunakan Metode Atmospheric Acid Leaching dalam Media Asam Klorida (HCl)
}

\author{
Dian Permana $^{1^{*}}$, Rizky Kumalasari ${ }^{2}$, Wahab $^{3}$, Musnajam ${ }^{2}$ \\ ${ }^{1}$ Kimia, Fakultas Sains dan Teknologi, Universitas Sembilanbelas November Kolaka, \\ Jalan Pemuda No. 339 Kolaka 93517, Indonesia \\ ${ }^{2}$ Teknik Pertambangan, Fakultas Sains dan Teknologi, Universitas Sembilanbelas November Kolaka, Jalan Pemuda \\ No. 339 Kolaka 93517, Indonesia \\ ${ }^{3}$ Teknik Pertambangan, Fakultas Kebumian, Universitas Halu Oleo, \\ Jl. H.E.A Mokodompit Kampus Hijau Bumi Tridharma Kendari, 93132, Indonesia
}

\begin{abstract}
ABSTRAK Ekstraksi nikel laterit menggunakan metode hidrometalurgi lebih efisien dari segi konsumsi energi dengan lebih sedikit gas buang dibandingkan dengan metode pirometalurgi. Oleh karena itu dengan metode hidrometalurgi hasil ekstraksi nikel laterit berkadar rendah bisa menjadi lebih banyak. Salah satu metode hidrometalurgi dalam mengekstraksi nikel dari bijih nikel laterit adalah Atmospheric Acid Leaching. Penelitian ini bertujuan untuk memperoleh berapa persentase perolehan nikeldan menentukan variabel yang paling berpengaruh dan kondisi optimum dalam proses pelindian. Pada penelitian ini faktor-faktor yang berpengaruh dalam proses leaching yakni temperatur, konsentrasi asam dan waktu pelindian dilakukan secara variatif. Analisis kandungan nikel hasil pelindian dilakukan menggunakan Atomic Adsorbtion Spectroscopy (AAS). Perhitungan ANOVA digunakan untuk menentukan faktor paling berpengaruh pada proses pelindian nikel laterit. Hasil penelitian menunjukkan bahwa persentase perolehan nikel terendah adalah 9,40\% Ni dan tertinggi $75,76 \%$ Ni. Faktor yang paling berpengaruh dalam penelitian ini adalah temperatur (A), diikuti konsentrasi asam (B),
\end{abstract}

Naskah masuk : 29 April 2020

Naskah direvisi : 3 Agustus 2020

Naskah diterima : 2 Oktober 2020

*Penulis korespondensi.

Email: asopermana@gmail.com waktu pelindian (C), interaksi konsentrasitemperatur $(\mathrm{AB})$, interaksi temperatur-waktu $(\mathrm{AC})$, interaksi konsentrasi-waktu (BC), dan interaksi konsentrasi-temperatur-waktu (ABC). Kondisi optimum pelindian diperoleh pada kondisi temperatur $75^{\circ} \mathrm{C}$, konsentrasi asam 2,9-3 Molar dalam waktu 69-70 menit dengan perolehan nikel $>70 \%$.

Kata kunci: pelindian, hidrometalurgi, asam klorida, nikel laterit.

ABSTRACT - The Leaching of Low-Grade Nickel Laterite Ore Using Atmospheric Acid Leaching Method in Hydrochloric Acid. Nickel laterite extraction using the hydrometallurgical method is more efficient in energy consumption with less exhaust gas than the pyrometallurgical method. This method causes the extraction of lowgrade nickel laterite ore using hydrometallurgy could be more effective. One of the hydrometallurgical methods to extract nickel from its ore is atmospheric acid leaching. This research aims to determine the percentage of nickel recovery through the leaching process, determine the most influenced leaching factor, and determine the optimum leaching condition. The main factors that influence the leaching process are temperature, acid concentration, and leaching time. Atomic adsorption spectroscopy was chosen to analyze the leaching solution. This research showed that the lowest recovery of nickel leaching was $9,40 \%$ of $\mathrm{Ni}$, and the highest was $75,76 \%$ of Ni. Analysis of variance (ANOVA) was used to determine the most influenced factor of leaching. The most influenced factor was temperature (A), followed by acid concentration (B), duration (C), interaction of acid concentration-temperature 
$(A B)$, interaction of temperature-duration $(A C)$, interaction of acid concentration-duration (BC), and interaction of acid concentrationtemperature-duration $(A B C)$. The optimum leaching condition is at $75^{\circ} \mathrm{C}$ of temperature, 2,93 molar of acid concentration, in 69-70 minutes of duration, which has $>70 \%$ of Ni recovery.

Keywords: leaching, hidrometalurgi, hydrochloric acid, nickel laterites.

\section{PENDAHULUAN}

Nikel merupakan logam strategis yang sering digunakan untuk produksi baja tahan karat dan campuran logam tanpa besi dengan kekuatan impak yang tinggi, ketahanan terhadap korosi yang tinggi, dan juga sifat lainnya yang diinginkan seperti sifat listrik, termal, dan magnetik (MacCarthy et al., 2016). Bijih nikel terbagi atas dua jenis, yaitu nikel sulfida dan nikel laterit (Solihin et al., 2014). Sekitar 70\% bijih nikel di dunia dikategorikan sebagai bijih nikel laterit (Marrero et al., 2015), tetapi lebih dari 60\% dari pengolahan nikel saat ini menggunakan bijih nikel sulfida sebagai bahan bakunya. Hal ini dikarenakan biaya ekstraksi yang lebih murah. Peningkatan permintaan secara global dan fluktuasi harga logam nikel di pasar komersial, serta berkurangnya cadangan bijih nikel sulfida, maka industri metalurgi mulai beralih untuk menggunakan bijih nikel laterit sebagai bahan bakunya (Tong et al., 2013).

Indonesia merupakan salah satu negara dengan potensi nikel terbesar di dunia termasuk bijih nikel laterit. Listyarini (2017) melaporkan profil endapan nikel laterit di daerah Palangga yang merupakan salah satu wilayah di Indonesia memiliki potensi nikel laterit yang melimpah. Saat ini, High-Pressure Acid Leaching (HPAL) dan pirometalurgi merupakan dua teknologi utama yang digunakan pada ekstraksi nikel laterit (Rao et al., 2013). Selama ini proses pengolahan nikel laterit di Indonesia umumnya menggunakan proses pirometalurgi yang memerlukan energi dan biaya sangat besar untuk menjalankan prosesnya (Listyarini, 2017). Beberapa cadangan bijih nikel dengan kadar yang tinggi sudah dieksploitasi dan diproses melalui jalur proses pirometalurgi untuk menghasilkan ferronikel ataupun nikel matte. Sedangkan pengolahan bijih nikel kadar rendah melalui proses pirometalurgi hanya akan menghasilkan low grade Nickel Pig Iron yang memiliki nilai jual rendah. Peningkatan kadar Nickel Pig Iron hanya bisa dilakukan dengan cara memasukkan bahan baku campuran bijih kadar rendah dan kadar tinggi sehingga diperoleh Nickel Pig Iron dengan kadar lebih tinggi. Alternatif proses untuk bijih nikel kadar rendah adalah jalur proses hidrometalurgi (Solihin \& Firdiyono, 2018).

Beberapa metode baru telah dikembangkan untuk memanfaatkan nikel laterit sebagai sumber nikel termasuk teknologi asam sulfat, klorida dan bioteknologi (McDonald \& Whittington, 2008a). Menurut Wang (2013), ekstraksi nikel laterit menggunakan metode hidrometalurgi lebih efisien dari segi konsumsi energi dengan lebih sedikit gas buang dibandingkan dengan metode pirometalurgi. Pengendalian proses hidrometalurgi dan sirkulasi media pelindi juga lebih sederhana dibanding jalur pirometalurgi. Sehingga nikel laterit berkadar rendah dapat diekstraksi lebih banyak menggunakan metode hidrometalurgi. Salah satu metode hidrometalurgi dalam mengekstraksi nikel dari bijih nikel laterit adalah Atmospheric Acid Leaching (AAL).

Pemanfaatan proses AAL ini dinilai efektif dari sisi penghematan energi dan kemurnian produk yang dihasilkan (McDonald \& Whittington, 2008b). Oleh karena itu, proses $A A L$ ini diharapkan dapat diaplikasikan dalam skala industri di Indonesia sehingga nikel laterit Indonesia dapat dimanfaatkan secara lebih efektif dan efisien. Beberapa metode pelindian menggunakan asam telah dilakukan seringkali dengan menggunakan asam sulfat. Keberadaan $\mathrm{SO}_{2}$ sebagai reduktan secara efektif dapat meningkatkan persentase pelindian nikel laterit hingga 97\% (Das \& de Lange, 2011). Untuk meningkatkan efektifitas pelindian dengan metode $A A L$ dapat ditambahkan senyawa natrium sulfit (Luo et al., 2015) dan amonium biflorida (Li et al., 2010).

Pelindian menggunakan asam klorida juga banyak menarik perhatian karena memungkinkan ekstraksi nikel dalam jumlah besar dalam waktu yang singkat. Proses pelindian berbasis klorida memiliki beberapa keuntungan dibandingkan proses hidrometalurgi konvensional yaitu hasil pelindian lebih tinggi, stabilitas tinggi dari kompleks kloro, dan regenerasi pereaksi pelindian ( Lakshmanan et al., 2016) 
Beberapa penelitian sebelumnya menggunakan asam klorida sebagai agen pelindian pada nikel laterit. Li et al. (2009) menyatakan adanya pengaruh pre-roasting terhadap pelindian nikel laterit yang menggunakan asam klorida. Faktor fisika-kimia mempengaruhi proses pelindian bahan mentah laterit pada asam klorida (Li et al., 2012). Ekstraksi nikel dan kobal dari lapisan saprolitik laterit dilakukan dengan menggunakan metode $A A L$ pada kondisi optimal yakni suhu 150 ${ }^{\circ} \mathrm{C}$, konsentrai $\mathrm{HCl} 350 \mathrm{~g} / \mathrm{L}$ dan waktu pelindian 90 menit (e.g Zhang et al., 2015). Pengembangan metode AAL berdasarkan pelindian menggunakan asam klorida telah dilakukan oleh Rice (2016). Pada penelitian ini, asam klorida akan digunakan sebagai media pelindian untuk ekstraksi nikel laterit pada lapisan limonit menggunakan metode $A A L$. Bagaimana pengaruh temperatur operasi, waktu pelindian dan konsentrasi asam klorida terhadap proses pelindian akan diteliti. Penggunaan Analysis of Variance (ANOVA) digunakan untuk menentukan variabel proses pelindian yang paling berpengaruh terhadap persentase perolehan nikel.

\section{METODE}

\section{Material}

Sampel dalam penelitian ini merupakan nikel laterit jenis limonit yang berasal dari PT. Sulemandara Konawe yang berlokasi di Kecamatan Pondidaha, Kabupaten Konawe, Provinsi Sulawesi Tenggara. Sampel selanjutnya dipreparasi oleh PT. Minertech Indonesia hingga memperoleh homogenitas yang baik dan mencapai target ukuran sampel yakni 200 mesh. Tabel 1 memperlihatkan komposisi unsur dan komposisi mineral nikel laterit yang digunakan pada penelitian ini. Bahan yang digunakan pada penelitian ini adalah asam klorida $(\mathrm{HCl}$, Merck) dan akuades.

\section{Pelindian bijih nikel laterit}

Proses pelindian diawali dengan memasukkan larutan asam klorida ( $\mathrm{HCl})$ konsentrasi $1 \mathrm{M}$ sebanyak $50 \mathrm{~mL}$ ke dalam reaktor untuk dipanaskan hingga mencapai suhu operasi $25{ }^{\circ} \mathrm{C}$. setelah suhu operasi tercapai, sampel sebanyak 10 gr dimasukkan ke dalam reaktor. Waktu pemasukan sampel ini terhitung sebagai waktu ke0 . Selama proses pelindian, setiap 30 menit dilakukan pengambilan larutan hasil pelindian sebanyak $5 \mathrm{~mL}$ untuk dianalisis menggunakan Atomic Absorption Spectroscopy (AAS). Proses yang sama juga dilakukan pada konsentrasi asam $2 \mathrm{M}$ dan $4 \mathrm{M}$ serta pada suhu operasi $50^{\circ} \mathrm{C}$ dan 75 ${ }^{\circ} \mathrm{C}$. Setelah proses pelindian selesai, larutan hasil pelindian kemudian disaring menggunakan kertas saring untuk memisahkan tailing dengan larutan hasil leaching.

\section{Pengolahan data}

Data analisa yang telah diperoleh dari proses analisis sampel dengan menggunakan alat $A A S$ diolah hingga diperoleh nilai persentase recovery nikel. Persentase recovery nikel merupakan persentase perbandingan konsentrasi nikel yang terukur dalam sampel cair dengan konsentrasi nikel awal yang terkandung dalam sampel nikel laterit. Penentuan persentase recovery nikel

Tabel 1. Hasil analisis X-Ray Fluorescence.

\begin{tabular}{lcc}
\hline \multirow{2}{*}{ Unsur/Senyawa } & \multicolumn{2}{c}{ Kadar } \\
\cline { 2 - 3 } $\mathrm{Ni}$ & 1,21 & $\boldsymbol{p} \boldsymbol{} \boldsymbol{m}$ \\
$\mathrm{Fe}$ & 22,03 & 22.100 \\
$\mathrm{Co}$ & 0,03 & 300 \\
$\mathrm{Al}_{2} \mathrm{O}_{3}$ & 6,85 & 68.530 \\
$\mathrm{SiO}_{2}$ & 33,13 & 331.300 \\
$\mathrm{CaO}$ & 0,27 & 2.700 \\
$\mathrm{MgO}$ & 4,77 & 47.680 \\
$\mathrm{Cr} 2 \mathrm{O}_{3}$ & 1,19 & 11.900 \\
$\mathrm{MnO}$ & 0,3 & 3.000 \\
$\mathrm{Fe} \mathrm{O}_{3}$ & 31,47 & 314.700 \\
$\mathrm{Cr}$ & 0,86 & 8.600 \\
$\mathrm{Al}$ & 3,62 & 36.280 \\
$\mathrm{Ca}$ & 0,15 & 1.500 \\
$\mathrm{Mn}$ & 0,23 & 2.300 \\
$\mathrm{P}$ & 0,006 & 60 \\
$\mathrm{~S}$ & 0,05 & 500 \\
\hline
\end{tabular}


dilakukan dengan menggunakan persamaan berikut :

$$
\alpha=\frac{C_{p o}}{C_{p}} \times 100 \%
$$

dimana $\alpha$ adalah persentase recovery nikel (\%), $\mathrm{C}_{\mathrm{p}}$ adalah konsentrasi nikel dalam sampel (ppm), $C_{p o}$ adalah konsentrasi nikel dalam larutan hasil leaching (ppm).

Analisis Ragam (Analysis of variance-ANOVA) tiga faktor dilakukan untuk menentukan variabel yang paling berpengaruh terhadap recovery unsur $\mathrm{Ni}$ serta untuk menentukan kondisi optimum proses pelindian. Dalam penelitian ini, variabel yang akan diamati yakni variasi temperatur reaksi, waktu pelindian dan konsentrasi asam.

\section{HASIL DAN PEMBAHASAN}

\section{Pelindian nikel}

Variasi terhadap faktor yang diamati dilakukan untuk mengetahui seberapa besar pengaruhnnya terhadap proses pelindian. Selain itu, dari variabel-variabel tersebut juga dapat ditentukan kondisi optimum proses pelindian. Setelah proses pelindian dilakukan, sampel-sampel yang berupa konsentrat selanjutnya dilakukan analisis kandungan Nikel (Ni) yang terlindi menggunakan Atomic Absorption Spectroscopy (AAS).

Hasil analisis $A A S$ pada Tabel 2 menunjukkan bahwa konsentrasi nikel yang terlindi dalam larutan asam semakin meningkat seiring dengan meningkatnya konsentrasi asam, temperatur dan waktu pelindian. Oleh karena itu, perubahan konsentrasi asam, temperatur dan waktu pelindian memiliki pengaruh yang signifikan terhadap terlindinya logam nikel.
Gambar 1 memperlihatkan bahwa konsentrasi nikel yang terlindi mengalami peningkatan seiring dengan meningkatnya konsentrasi asam, temperatur dan waktu pelindian. Dalam Gambar 1 (a), di waktu pelindian 30 menit, 60 menit dan 90 menit secara vertikal, peningkatan konsentrasi nikel terlindi jelas terlihat mengikuti peningkatan temperatur dan waktu pelindian, meskipun dalam konsentrasi asam yang konstan. Pada konsentrasi asam 1 Molar, konsentrasi nikel terlindi paling rendah tedapat pada suhu $25{ }^{\circ} \mathrm{C}$ dan waktu pelindian selama 30 menit yakni sebesar 1.136,36 ppm. Sedangkan konsentrasi nikel hasil leaching paling tinggi terdapat pada suhu $75{ }^{\circ} \mathrm{C}$ dengan waktu pelindian selama 90 menit yakni sebesar $5000 \mathrm{ppm}$. Hal yang sama juga tergambar pada grafik (b) dan (c) dimana peningkatan konsentrasi nikel terlindi tetap mengikuti perubahan temperatur dan waktu pelindian untuk masingmasing konsentrasi $2 \mathrm{M}$ dan $4 \mathrm{M}$.

\section{Persentase pelindian nikel}

Persentase perolehan nikel terlindi merupakan perbandingan antara kadar nikel yang terkandung dalam sampel cair hasil proses pelindian dengan kadar nikel dalam sampel padat nikel laterit. Untuk menghitung persentase perolehan nikel terlindi, digunakan Persamaan 1.

Zhang et al. (2015) melakukan leaching pada konsentrasi $\mathrm{HCl} 350 \mathrm{gr} / \mathrm{l}(9,58 \mathrm{M})$, temperatur 150 ${ }^{\circ} \mathrm{C}$ selama 90 menit dengan menggunakan sampel nikel laterit berkadar Ni 1,37\%. Nikel yang dapat diekstraksi pada kondisi tersebut adalah hampir mencapai 90\%. Jika dibandingkan dengan data pada Tabel 3, pada konsentrasi $4 \mathrm{M}$, temperatur 75 ${ }^{\circ} \mathrm{C}$ selama 90 menit, nikel yang dapat diektraksi hanya sekitar $75 \%$. Perbedaan hasil ektraksi tersebut diakibatkan oleh perbedaan konsentrasi

Tabel 2. Nikel terlindi (

\begin{tabular}{|c|c|c|c|c|c|c|c|c|c|}
\hline \multirow[b]{2}{*}{$\begin{array}{c}\text { Konsentrasi } \\
\text { (Molar) }\end{array}$} & \multicolumn{3}{|c|}{ Temperatur $25^{\circ} \mathrm{C}$} & \multicolumn{3}{|c|}{ Temperatur $50^{\circ} \mathrm{C}$} & \multicolumn{3}{|c|}{ Temperatur $7^{\circ} \mathrm{C}$} \\
\hline & $\begin{array}{c}\text { Waktu } \\
\mathbf{3 0} \\
\text { Menit }\end{array}$ & $\begin{array}{c}\text { Waktu } \\
60 \\
\text { Menit }\end{array}$ & $\begin{array}{c}\text { Waktu } \\
90 \\
\text { Menit }\end{array}$ & $\begin{array}{c}\text { Waktu } \\
\mathbf{3 0} \\
\text { Menit }\end{array}$ & $\begin{array}{c}\text { Waktu } \\
60 \\
\text { Menit }\end{array}$ & $\begin{array}{c}\text { Waktu } \\
90 \\
\text { Menit }\end{array}$ & $\begin{array}{c}\text { Waktu } \\
\mathbf{3 0} \\
\text { Menit }\end{array}$ & $\begin{array}{c}\text { Waktu } \\
60 \\
\text { Menit }\end{array}$ & $\begin{array}{c}\text { Waktu } \\
90 \\
\text { Menit }\end{array}$ \\
\hline 1 & $1.136,37$ & $1.515,16$ & $1.742,43$ & $1.363,64$ & $1.742,43$ & $2.121,22$ & $3.181,82$ & $4.393,94$ & $5.000,00$ \\
\hline 2 & $2.371,22$ & $3.106,06$ & $3.560,61$ & $2.500,00$ & $3.636,36$ & $4.166,66$ & $4.772,73$ & $7.045,45$ & $7.348,48$ \\
\hline 4 & $3.106,06$ & $3.863,64$ & $4.318,18$ & $3.560,60$ & $4.545,45$ & $5.075,76$ & $6.590,91$ & $8.030,30$ & $9.166,66$ \\
\hline
\end{tabular}


a)

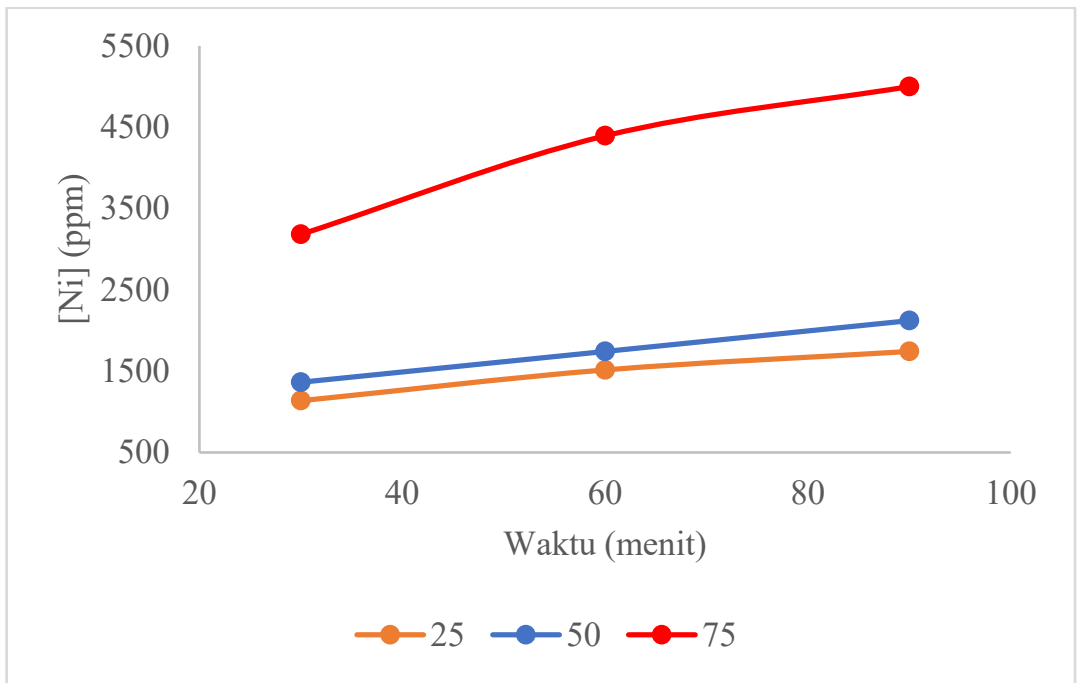

b)

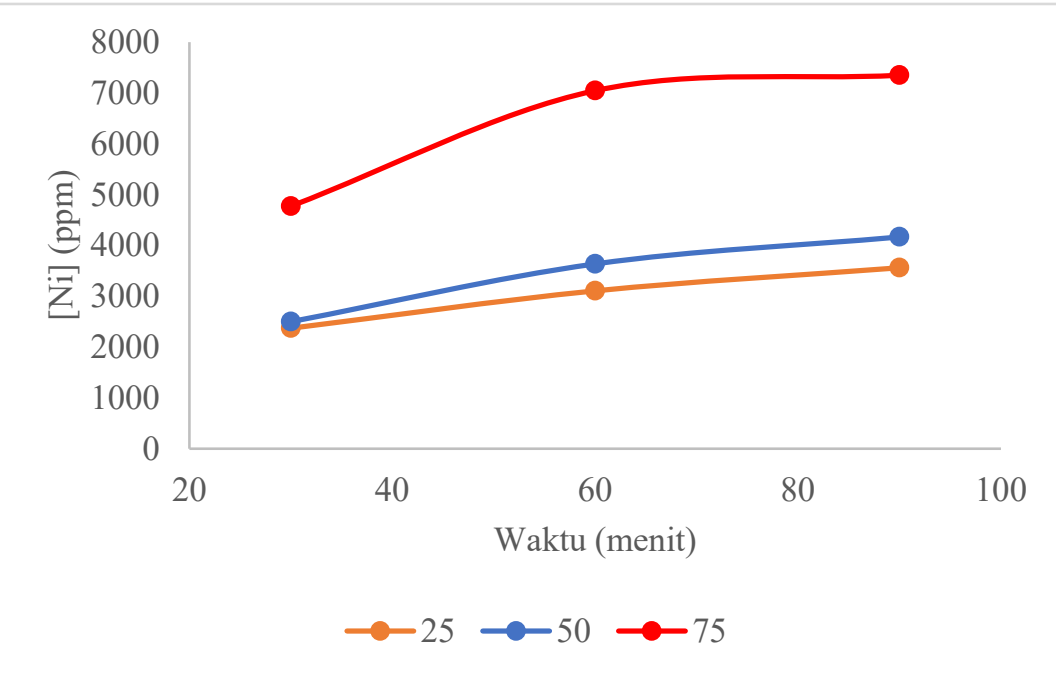

c)

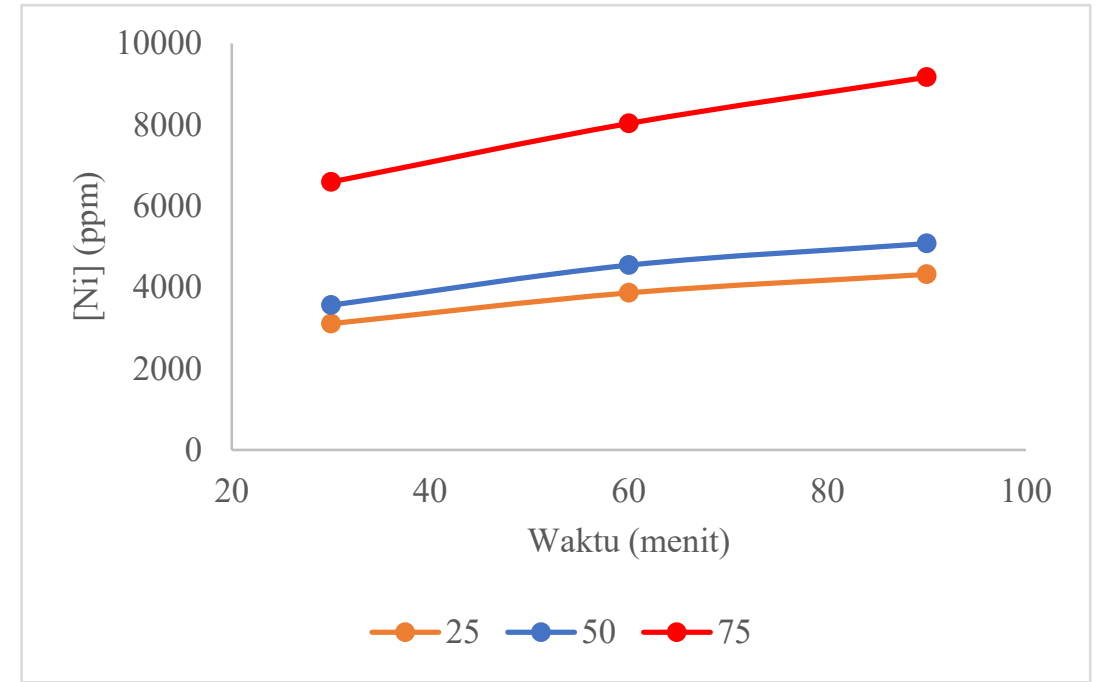

Gambar 1. Grafik peningkatan konsentrasi nikel terlindi pada (a) Konsentrasi $\mathrm{HCl} 1 \mathrm{M}$, (b) Konsentrasi $\mathrm{HCl} 2 \mathrm{M}$, (c) Konsentrasi $\mathrm{HCl} 4 \mathrm{M}$. 
Tabel 3. Perolehan nikel terlindi (\%).

\begin{tabular}{|c|c|c|c|c|c|c|c|c|c|}
\hline \multirow[b]{2}{*}{$\begin{array}{c}\text { Konsentrasi } \\
\text { (Molar) }\end{array}$} & \multicolumn{3}{|c|}{ Temperatur $25^{\circ} \mathrm{C}$ [B1] } & \multicolumn{3}{|c|}{ Temperatur $50^{\circ} \mathrm{C}$ [B2] } & \multicolumn{3}{|c|}{ Temperatur $75^{\circ} \mathrm{C}$ [B3] } \\
\hline & $\begin{array}{c}\text { Waktu } \\
\text { 30 } \\
\text { Menit } \\
\text { [C1] }\end{array}$ & $\begin{array}{c}\text { Waktu } \\
60 \\
\text { Menit } \\
\text { [C2] }\end{array}$ & $\begin{array}{c}\text { Waktu } \\
90 \\
\text { Menit } \\
\text { [C3] }\end{array}$ & $\begin{array}{c}\text { Waktu } \\
\text { 30 } \\
\text { Menit } \\
{[C 1]}\end{array}$ & $\begin{array}{c}\text { Waktu } \\
60 \\
\text { Menit } \\
\text { [C2] }\end{array}$ & $\begin{array}{c}\text { Waktu } \\
90 \\
\text { Menit } \\
{[C 3]}\end{array}$ & $\begin{array}{c}\text { Waktu } \\
30 \\
\text { Menit } \\
\text { [C1] }\end{array}$ & $\begin{array}{c}\text { Waktu } \\
60 \\
\text { Menit } \\
{[C 2]}\end{array}$ & $\begin{array}{c}\text { Waktu } \\
90 \\
\text { Menit } \\
\text { [C3] }\end{array}$ \\
\hline 1 & 9,40 & 12,52 & 14,40 & 11,27 & 14,40 & 17,53 & 26,30 & 36,32 & 41,32 \\
\hline 2 & 19,60 & 25,67 & 29,43 & 20,67 & 30,05 & 34,44 & 39,45 & 58,23 & 60,74 \\
\hline 4 & 25,67 & 31,93 & 35,69 & 29,43 & 37,57 & 41,95 & 54,47 & 66,37 & 75,76 \\
\hline
\end{tabular}

asam dan temperatur pelindian yang sangat jauh. Oleh karena itu konsentrasi asam dan temperatur pelindian sangat berpengaruh terhadap hasil yang diperoleh.

Dalam penelitian lain yang dilakukan oleh Li et al. (2018), proses leaching dilakukan pada kondisi konsentrasi $\mathrm{HCl} 2 \mathrm{M}$, temperatur $90{ }^{\circ} \mathrm{C}$ selama 90 menit dengan kadar nikel awal 1,15\% serta adanya penambahan katalis ammonium klorida sebanyak $3 \mathrm{M}$. Nikel yang dapat diekstraksi pada kondisi tersebut mencapai $87,7 \%$. Jika dibandingkan dengan Tabel 3 pada kondisi konsentrasi $\mathrm{HCl} 2 \mathrm{M}$, temperatur $75^{\circ} \mathrm{C}$ selama 90 menit, nikel yang dapat diekstraksi hanya sekitar $60 \%$. Berdasarkan hal tersebut, maka peningkatan temperatur dan penambahan katalis dalam proses pelindian juga berpengaruh terhadap hasil ekstraksi.

\section{Pengaruh temperatur}

Temperatur merupakan salah satu faktor yang mempengaruhi proses pelindian. Dalam penelitian ini, temperatur pelindian divariasikan pada $25^{\circ} \mathrm{C}$, $50{ }^{\circ} \mathrm{C}$, dan $75{ }^{\circ} \mathrm{C}$. Gambar 2 menunjukkan persentase perolehan nikel yang terus meningkat seiring peningkatan temperatur. Hal ini mengindikasikan bahwa proses pelindian diaktivasi oleh peningkatan suhu. Pada temperatur $25{ }^{\circ} \mathrm{C}$ persentase perolehan nikel terus mengalami peningkatan seiring dengan meningkatnya konsentrasi asam dan waktu pelindian. Persentase terendah terdapat pada kondisi 30 menit - $1 \mathrm{M}$ dengan perolehan 9,39\% Ni. Sedangkan perolehan tertinggi terdapat pada kondisi 90 menit - 4 M dengan perolehan 54,47\% Ni. Begitu pula yang terjadi pada temperatur $50^{\circ} \mathrm{C}$ dan $75^{\circ} \mathrm{C}$.

Ditinjau secara horizontal, persentase perolehan nikel juga meningkat mengikuti perubahan suhu dan waktu dengan konsentrasi asam tetap. Seperti pada kondisi 30 menit - $1 \mathrm{M}$, persentase terendah diperoleh pada suhu $25{ }^{\circ} \mathrm{C}$ yakni sebesar 9,39\% Ni. Peningkatan persentase perolehan nikel akan terus naik mengikuti peningkatan suhu hingga mencapai $14,4 \%$ pada suhu $75{ }^{\circ} \mathrm{C}$. Peningkatan perolehan nikel juga ditunjukkan pada waktu dan konsentrasi asam yang lebih tinggi berikutnya.

Hasil serupa telah ditunjukkan oleh penelitian sebelumnya yang dilakukan oleh Aras \& Ağaçayak, (2017), dimana uji pelindian nikel laterit menggunakan larutan asam klorida divariasikan pada temperatur $40{ }^{\circ} \mathrm{C}, 50^{\circ} \mathrm{C}, 60^{\circ} \mathrm{C}$, dan $70{ }^{\circ} \mathrm{C}$. Hasilnya menunjukkan bahwa meningkatnya konsentrasi nikel terlindi seiring dengan peningkatan temperatur pelindian. Peningkatan konsentrasi nikel terlindi ditunjukkan lebih signifikan terjadi pada temperatur diatas $60{ }^{\circ} \mathrm{C}$ dibandingkan pada temperatur dibawah $60{ }^{\circ} \mathrm{C}$. Hal yang sama ditunjukkan Pada Gambar 2, dimana persentase perolehan nikel terlindi lebih tinggi pada temperatur diatas $50{ }^{\circ} \mathrm{C}$ dibandingkan temperatur dibawah $50{ }^{\circ} \mathrm{C}$.

Dalam proses pelindian, kenaikan temperatur meningkatkan kecepatan tumbukan antar molekul. Hal ini disebabkan karena temperatur memberikan energi kepada ion-ion dalam sampel maupun pelarut untuk bergerak. Semakin tinggi temperatur maka semakin cepat ion-ion bergerak, sehingga kemungkinan terjadinya tumbukan antar ion semakin tinggi. Akibatnya, laju reaksi akan semakin cepat sehingga pembentukan produk nikel klorida semakin banyak.

\section{Pengaruh konsentrasi asam}

Konsentrasi asam juga merupakan salah satu faktor yang mempengaruhi proses pelindian. Dalam penelitian ini, konsentrasi asam divariasikan pada $1 \mathrm{M}, 2 \mathrm{M}$, dan $4 \mathrm{M}$. Gambar 3 memperlihatkan bahwa persentase perolehan nikel meningkat seiring dengan meningkatnya 


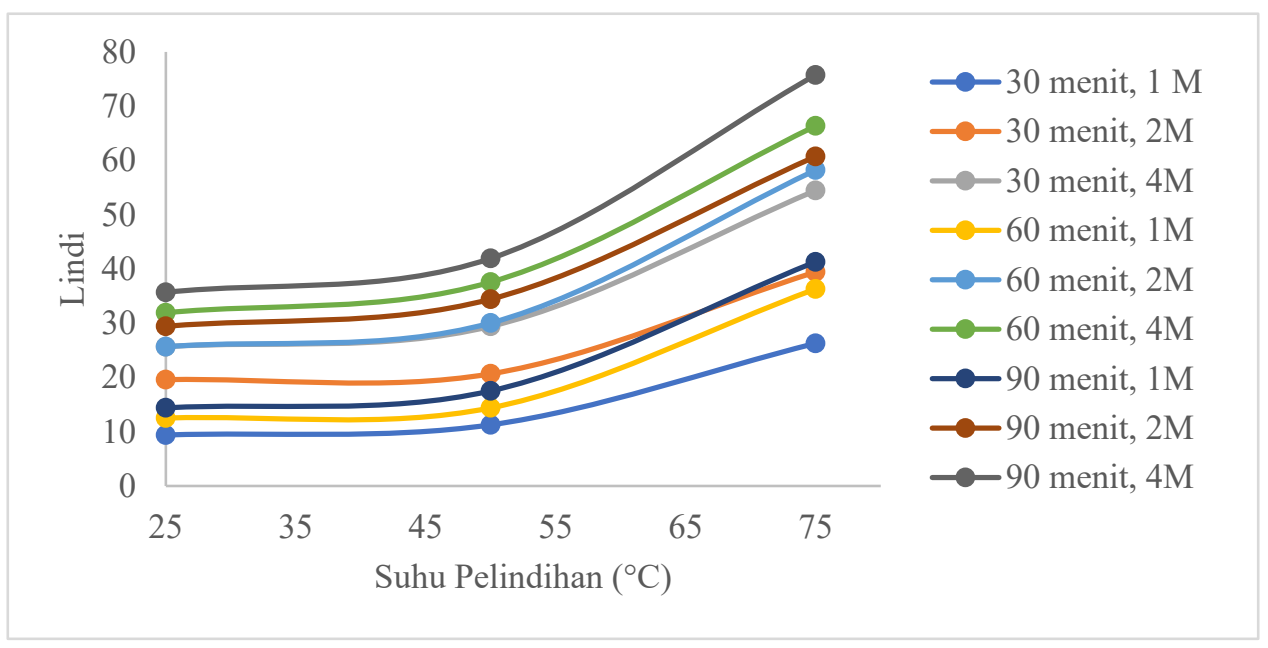

Gambar 2. Pengaruh temperatur pelindian terhadap \% perolehan kembali Ni.

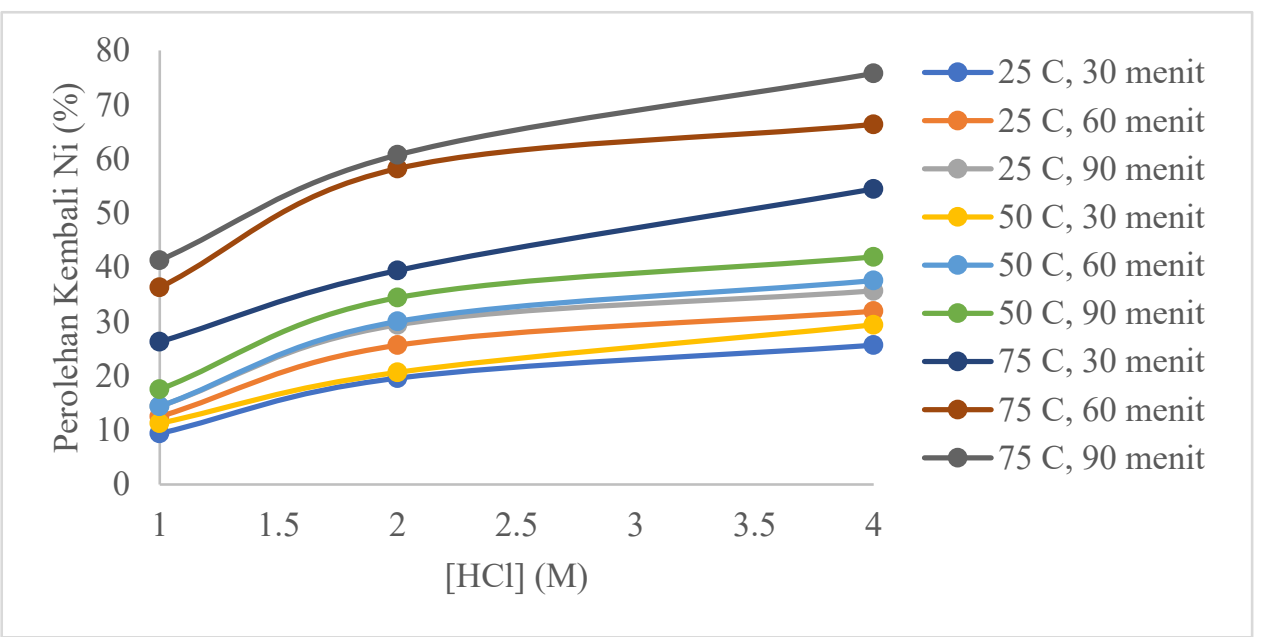

Gambar 3. Pengaruh konsentrasi asam terhadap \% perolehan kembali Ni.

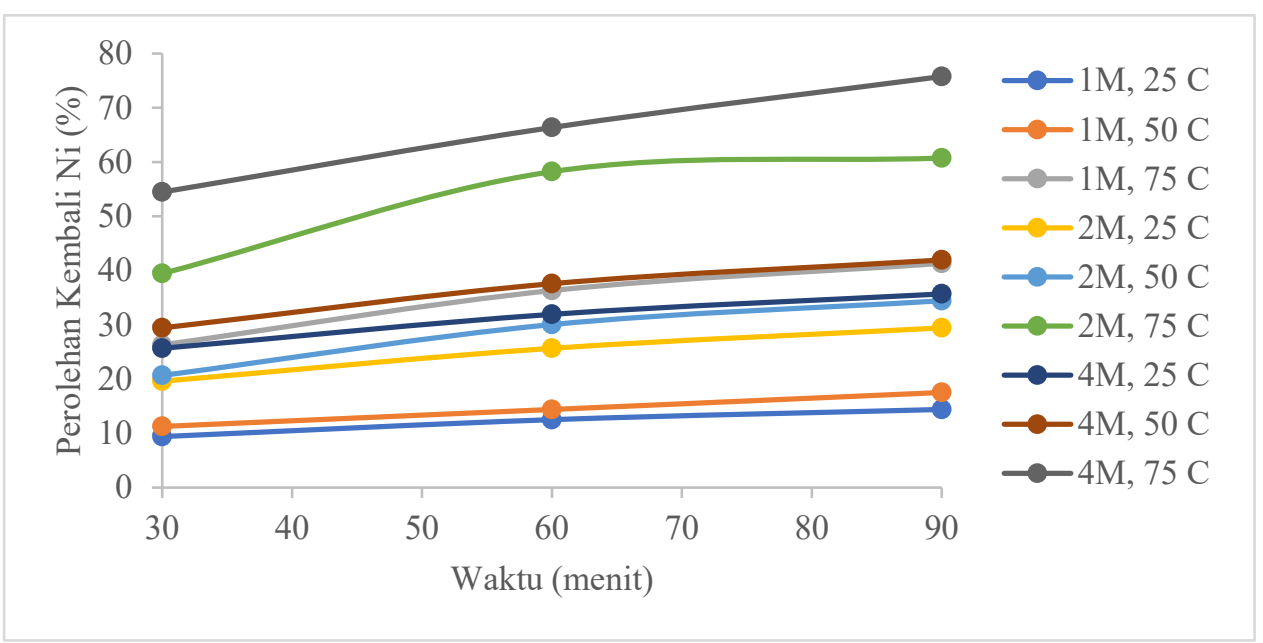

Gambar 4. Pengaruh waktu perlindian terhadap \% recovery Ni. 
konsentrasi asam. Pada konsentrasi $\mathrm{HCl} 1 \mathrm{M}$, persentase terendah terpadat pada kondisi $25^{\circ} \mathrm{C}-$ 30 Menit dengan perolehan 9,39\% Ni. Sedangkan perolehan terbesar untuk konsentrasi $1 \mathrm{M}$ terdapat pada kondisi $75^{\circ} \mathrm{C}-90$ menit dengan perolehan $41,32 \% \mathrm{Ni}$. Hal yang sama juga terlihat pada konsentrasi $\mathrm{HCl} 2 \mathrm{M}$ dan $4 \mathrm{M}$.

Hal tersebut juga telah dijelaskan oleh (Miazga \& Mulak, 2008) yang melakukan uji pelindian nikel laterit menggunakan larutan asam klorida divariasikan pada konsentrasi asam $1 \mathrm{M}, 2 \mathrm{M}, 3$ $\mathrm{M}$, dan 5M. Hasilnya menunjukkan persentase perolehan nikel meningkat seiring dengan meningkatnya konsentrasi asam. Peningkatan persentase perolehan nikel secara signifikan terjadi pada konsentrasi $\mathrm{HCl} 1 \mathrm{M}-3 \mathrm{M}$.

Dalam penelitian ini, konsentrasi asam menunjukkan seberapa banyak jumlah ion $\mathrm{H}^{+}$ dalam larutan asam. Semakin banyak ion $\mathrm{H}^{+}$ dalam larutan asam maka kemungkinan terjadinya reaksi antara ion $\mathrm{H}^{+}$dengan molekul $\mathrm{NiO}$ semakin besar. Reaksi antara ion $\mathrm{H}^{+}$dan $\mathrm{Cl}^{-}$dengan molekul $\mathrm{NiO}$ dalam sampel akan menghasilkan produk nikel klorida dan air (Astuti et al., 2016).

\section{Pengaruh waktu}

Waktu pelindian juga merupakan salah satu faktor yang berpengaruh terhadap proses pelindian. Waktu pelindian dalam penelitian ini dimaksudkan pada seberapa lama terjadinya kontak antara sampel nikel laterit dengan media pelarutnya. Gambar 4 memperlihatkan bahwa pada waktu 30 menit, persentase perolehan nikel akan meningkat seiring dengan bertambahnya temperatur dan konsentrasi asam. Perolehan terendah terdapat pada kondisi $1 \mathrm{M}-25{ }^{\circ} \mathrm{C}$ yakni sebesar 9,38\% Ni. Sementara perolehan tertinggi terdapat pada kondisi $4 \mathrm{M}-75^{\circ} \mathrm{C}$ yakni sebesar $35,69 \% \mathrm{Ni}$. Hal yang sama juga ditunjukkan pada waktu 60 menit dan 90 menit.

Hasil serupa juga telah ditunjukkan pada penelitian yang dilakukan oleh Li et al. (2018) yang melakukan pelindian bijih nikel laterit menggunakan asam klorida divariasikan pada waktu pelindian 30, 60, 90, dan 120 menit. Hasil penelitiannya menunjukkan peningkatan persentase perolehan nikel seiring dengan semakin lamanya kontak antara sampel dengan pelarut. Waktu pelindian diatas 60 menit menunjukkan persentase perolehan nikel cenderung meningkat lebih signifikan dibanding waktu pelindian dibawah 60 menit. Hal ini mengindikasikan bahwa seiring bertambahnya waktu maka semakin optimum kontak antara sampel nikel laterit dengan pelarutnya dalam proses pelindian. Semakin optimalnya kontak sampel dengan pelarut mengakibatkan reaksi pengikatan logam nikel oleh pelarut akan semakin baik.

\section{Analysis of Variance (ANOVA)}

Analysis of Variance 3 faktor dilakukan untuk menentukan variabel proses pelindian yang paling berpengaruh terhadap persentase perolehan nikel.

Tabel 4. Data hasil perhitungan ANOVA.

\begin{tabular}{cccccccc}
\hline Faktor & SS & $\begin{array}{c}\text { Degree of } \\
\text { Freedom }\end{array}$ & MS & $\mathbf{F}_{\mathbf{0}}$ & Fa & P-value & Rank \\
\hline A & 5263 & 2 & 2631,50 & 1065,06 & 3,350 & 0,00 & 2 \\
B & 8522,206 & 2 & 4261,103 & 1724,61 & 3,350 & 0,00 & 1 \\
$\mathbf{C}$ & 1525,06 & 2 & 762,53 & 308,62 & 3,350 & 0,00 & 3 \\
AB & 231,2649 & 4 & 57,82 & 23,40 & 2,730 & 0,00 & 4 \\
AC & 92,22 & 4 & 23,06 & 9,33 & 2,730 & 0,00 & 6 \\
BC & 215,675 & 4 & 53,92 & 21,82 & 2,730 & 0,00 & 5 \\
ABC & 23,159 & 8 & 2,89 & 1,17 & 2,310 & 0,353 & 7 \\
Error & 66,71 & 27 & 2,47 & & & & \\
Total & 15939,3 & 53 & & & & & \\
\hline
\end{tabular}


Hasil perhitungan ANOVA pada Tabel 4 menunjukkan urutan faktor yang paling berpengaruh dalam presentase perolehan nikel dalam pelindian. Faktor yang paling berpengaruh yaitu temperatur (B), diikuti oleh konsentrasi (A), waktu pelindian (C), interaksi konsentrasitemperatur ( $\mathrm{AB})$, interaksi temperatur-waktu (BC), interaksi konsentrasi-waktu (BC), dan interaksi konsentrasi-temperatur-waktu (ABC).

Berdasarkan data persentase perolehan nikel hasil pelindian (Tabel 3), dapat dibuat persamaan regresi. Persamaan regresi digunakan untuk memprediksi persentase recovery nikel jika nilai variabel yang digunakan lebih tinggi ataupun lebih rendah dari penelitian ini. Persamaan regresi ditentukan dengan menggunakan Minitab
Software 16 yang diproduksi oleh Minitab Ltd tahun 2015. Data persentase perolehan nikel dibuat tiga persamaan regresi pada tiga variasi temperatur, yaitu $25^{\circ} \mathrm{C}, 50^{\circ} \mathrm{C}$ dan $75^{\circ} \mathrm{C}$. Variabel $\mathrm{x}_{1}$ merupakan Konsentrasi asam dan $\mathrm{x}_{2}$ adalah Waktu pelindian serta y merupakan persentase perolehan nikel. Persamaan regresi dari data ANOVA disajikan pada Tabel 5.

Contour plot dan respon surface dibuat untuk membantu menggambarkan hubungan persentase perolehan nikel dalam variasi konsentrasi asam, temperatur dan waktu pelindian. Contour plot dan respon surface dibuat menggunakan Minitab. Contour plot dan respon surface disajikan pada Gambar 5.

Tabel 5. Persamaan regresi untuk persentase perolehan nikel.

\begin{tabular}{|c|c|c|c|}
\hline Temperatur $\left({ }^{\circ} \mathrm{C}\right)$ & Persamaan Regresi & $\mathbf{S}$ & $\mathbf{R}^{2}$ \\
\hline 25 & $y=-18,22+22,13 x_{1}+0,261 x_{2}-3,358 x_{1}^{2}-0,00133 x_{2}^{2}+0,0187 x_{1} x_{2}$ & 1,761 & 0,971 \\
\hline 50 & $y=-21,23+23,56 x_{1}+0,361 x_{2}-3,486 x_{1}^{2}-0,001866 x_{2}^{2}+0,0221 x_{1} x_{2}$ & 1,716 & 0,980 \\
\hline 75 & $y=-19,62+28,16 x_{1}+0,799 x_{2}-3,931 x_{1}^{2}-0,00441 x_{2}^{2}+0,0298 x_{1} x_{2}$ & 2,412 & 0,983 \\
\hline
\end{tabular}

a)

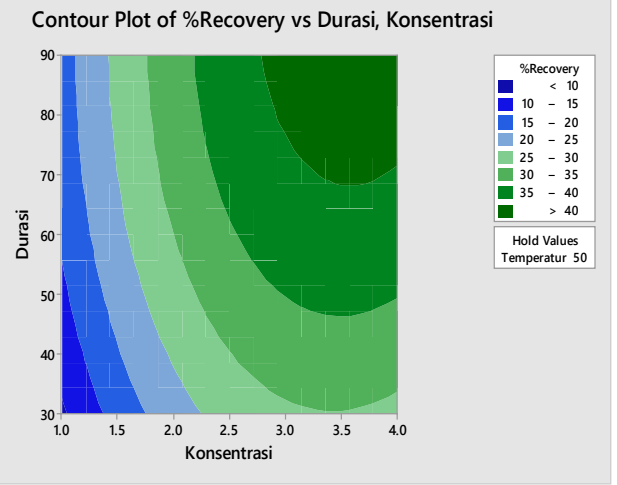

b)

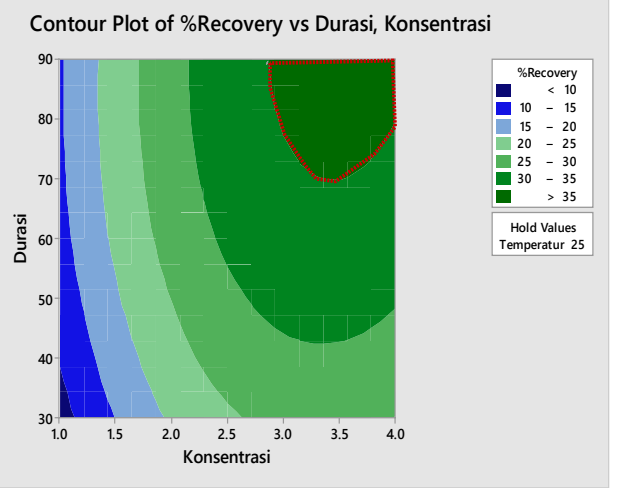

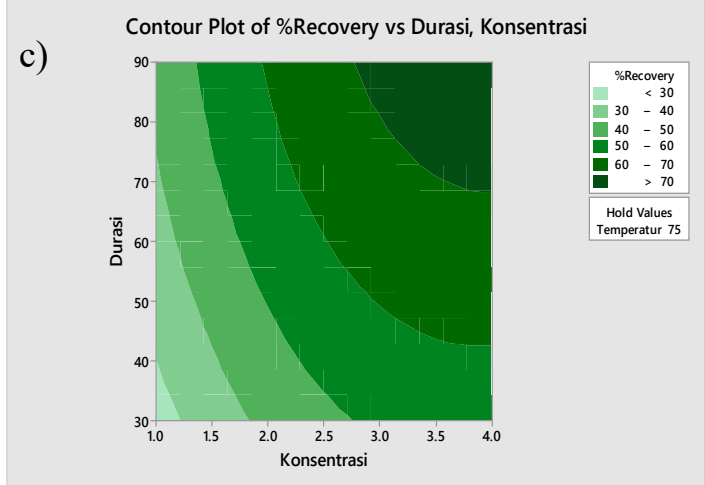

Gambar 5. Contour plot perolehan nikel pada (a) $25^{\circ} \mathrm{C}$, (b) $50{ }^{\circ} \mathrm{C}$, dan (c) $75^{\circ} \mathrm{C}$. 
Berdasarkan Gambar 5 dan 6, temperatur dijadikan sebagai variabel tetap untuk setiap perubahan konsentrasi dan waktu pelindian. Contour plot dan respon surface pada temperatur $25{ }^{\circ} \mathrm{C}$ (Gambar 6a dan Gambar 7a) menunjukkan persentase perolehan nikel $>35 \%$ telah diperoleh pada konsentrasi asam 3 Molar dengan waktu pelindian selama 70 menit. Pada temperatur $50^{\circ} \mathrm{C}$ (Gambar 6b dan Gambar 7b) persentase perolehan nikel $>40 \%$ telah diperoleh pada konsentrasi asam sedikit dibawah 3 Molar hanya dalam waktu 70 menit. Untuk temperatur $75{ }^{\circ} \mathrm{C}$ (Gambar 6c dan Gambar 7c) persentase perolehan nikel $>70 \%$ telah diperoleh pada konsentrasi asam sedikit dibawah 3 Molar hanya dalam waktu 69 menit. Sehingga dapat disimpulkan bahwa kondisi optimum pelindian dengan persentase perolehan nikel $>70 \%$ dapat dicapai pada temperatur $75{ }^{\circ} \mathrm{C}$ dengan konsentrasi asam 2,9 - 3 Molar dalam waktu $69-70$ menit.

\section{KESIMPULAN}

Persentase perolehan nikel dalam proses pelindian dipengaruhi oleh variasi temperatur, konsentrasi asam dan waktu pelindian. Semakin tinggi temperatur, konsentrasi asam dan waktu pelindian maka persentase perolehan nikel akan semakin tinggi pula. Dalam penelitian ini, persentase perolehan nikel terendah terdapat pada kondisi temperatur $25^{\circ} \mathrm{C}$, konsentrasi asam 1 Molar dalam waktu 30 menit yakni sebesar $9,39 \% \mathrm{Ni}$. Sedangkan perolehan tertinggi terdapat pada kondisi temperatur $75^{\circ} \mathrm{C}$, konsentrasi asam 4 Molar dalam waktu 90 menit dengan perolehan sebesar $75,76 \% \mathrm{Ni}$.

Berdasarkan hasil perhitungan ANOVA 3 faktor, urutan variabel yang paling berpengaruh terhadap proses pelindian yaitu temperatur (B), diikuti oleh konsentrasi (A), waktu pelindian (C), interaksi konsentrasi-temperatur $\quad(\mathrm{AB}), \quad$ interaksi
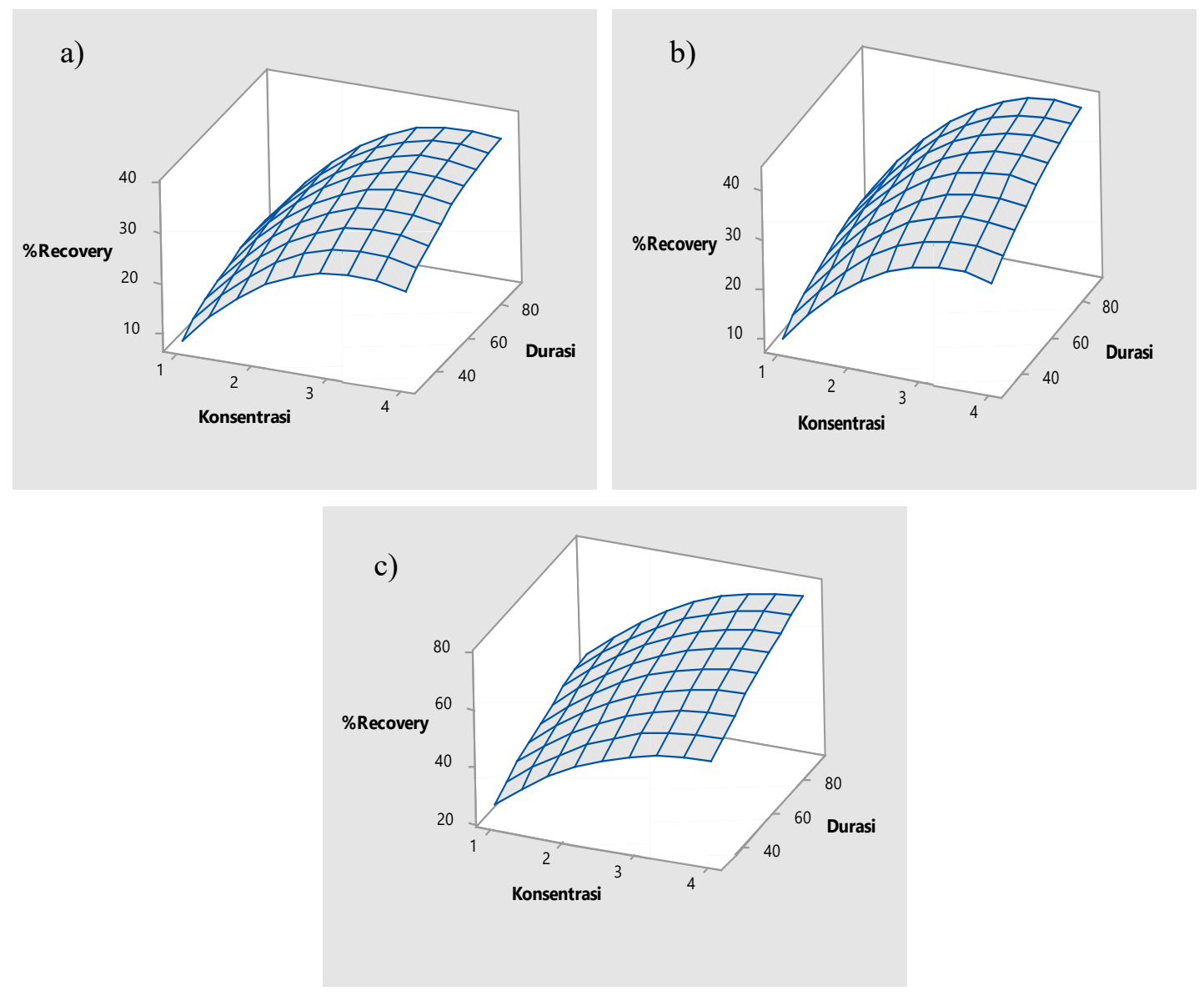

Gambar 6. Respon surface persentase perolehan nikel pada (a) $25^{\circ} \mathrm{C}$, (b) $50^{\circ} \mathrm{C}$, dan $\quad$ (c) $75^{\circ} \mathrm{C}$. 
temperatur-durasi (BC), interaksi konsentrasidurasi (AC), dan interaksi konsentrasi-temperaturdurasi (ABC). Dan berdasarkan contour plot dan respon surface, kondisi optimum pelindian nikel diperoleh pada kondisi temperatur $75{ }^{\circ} \mathrm{C}$, konsentrasi asam 2,9-3 M dalam waktu $69-70$ menit dengan perolehan nikel $>70 \%$.

\section{DAFTAR PUSTAKA}

Aras, A., \& A ğaçayak, T., 2017. Optimization of nickel extraction from lateritic ore in hydrochloric acid solution with hydrogen peroxide by taguchi method. Journal of Engineering Science and Technology, 5(3), 341-352.

Astuti, W., Hirajima, T., Sasaki, K., \& Okibe, N., 2016. Comparison of effectiveness of citric acid and other acids in leaching of low-grade Indonesian saprolitic ores. Minerals Engineering, 85, 1-16. https://doi.org/10.1016/j.mineng.2015.10 .001

Das, G. K., \& de Lange, J. A. B., 2011. Reductive atmospheric acid leaching of West Australian smectitic nickel laterite in the presence of sulphur dioxide and copper (II). Hydrometallurgy, 105(3), 264-269. https://doi.org/10.1016/j.hydromet.2010. 10.016

Lakshmanan, V. I., Sridhar, R., Chen, J., \& Halim, M. A., 2016. Development of MixedChloride Hydrometallurgical Processes for the Recovery of Value Metals from Various Resources. Transactions of the Indian Institute of Metals, 69(1), 39-50. https://doi.org/10.1007/s12666-0150626-5

Li, G., Rao, M., Li, Q., Peng, Z., \& Jiang, T., 2010. Extraction of cobalt from laterite ores by citric acid in presence of ammonium bifluoride. Transaction of nonferrous metals societyof China, 8(12), 1517 1520. https://doi.org/10.1016/S10036326(09)60331-9

Li, J., Li, D., Xu, Z., Liao, C., Liu, Y., \& Zhong, B., 2018. Selective leaching of valuable metals from laterite nickel ore with ammonium chloride-hydrochloric acid solution. Journal of Cleaner Production,
179 ,

https://doi.org/10.1016/j.jclepro.2018.01. 085

Li, J., Li, X., Hu, Q., Wang, Z., Zhou, Y., Zheng, J., Liu, W., \& Li, L., 2009. Effect of preroasting on leaching of laterite. Hydrometallurgy, 99(1), 84-88. https://doi.org/10.1016/j.hydromet.2009. 07.006

Li, J., Xiong, D., Chen, H., Wang, R., \& Liang, Y., 2012. Physicochemical factors affecting leaching of laterite ore in hydrochloric acid. Hydrometallurgy, 129-130, 14-18. https://doi.org/10.1016/j.hydromet.2012. 08.001

Listyarini, S., 2017. Designing Heap Leaching for Nickel Production that Environmentally and Economically Sustain. 8(12), 799803.

https://doi.org/10.18178/ijesd.2017.8.12. 1060

Luo, J., Li, G., Rao, M., Peng, Z., Zhang, Y., \& Jiang, T., 2015. Atmospheric leaching characteristics of nickel and iron in limonitic laterite with sulfuric acid in the presence of sodium sulfite. Minerals Engineering, 78, 38-44. https://doi.org/10.1016/j.mineng.2015.03 .030

MacCarthy, J., Nosrati, A., Skinner, W., \& AddaiMensah, J., 2016. Atmospheric acid leaching mechanisms and kinetics and rheological studies of a low grade saprolitic nickel laterite ore. Hydrometallurgy, $160, \quad 26-37$. https://doi.org/10.1016/j.hydromet.2015. 11.004

Marrero, J., Coto, O., Goldmann, S., Graupner, T., \& Schippers, A., 2015. Recovery of Nickel and Cobalt from Laterite Tailings by Reductive Dissolution under Aerobic Conditions Using Acidithiobacillus Species. Environmental Science \& Technology, 49(11), 6674-6682. https://doi.org/10.1021/acs.est.5b00944

McDonald, R. G., \& Whittington, B. I., 2008a. Atmospheric acid leaching of nickel laterites review: Part I. Sulphuric acid technologies. Hydrometallurgy, 91(1), 
$35-55$.

https://doi.org/10.1016/j.hydromet.2007. 11.009

McDonald, R. G., \& Whittington, B. I., 2008b. Atmospheric acid leaching of nickel laterites review. Part II. Chloride and biotechnologies. Hydrometallurgy, 91(1), 56-69.

https://doi.org/10.1016/j.hydromet.2007. 11.010

Miazga, B., \& Mulak, W., 2008. Leaching of nickel from spent catalysts in hydrochloric acid solutions. Physicochemical Problems of Mineral Processing, 42(1), 177-184.

Rao, M., Li, G., Jiang, T., Luo, J., Zhang, Y., \& Fan, X., 2013. Carbothermic Reduction of Nickeliferous Laterite Ores for Nickel Pig Iron Production in China: A Review. JOM, 65(11), 1573-1583. https://doi.org/10.1007/s11837-0130760-7

Rice, N. M., 2016. A hydrochloric acid process for nickeliferous laterites. Minerals Engineering, $88, \quad 28-52$. https://doi.org/10.1016/j.mineng.2015.09 .017

Solihin, Mubarok, M. Z., Hapid, A., \& Firdiyono, F., 2014. Pelindian bijih nikel laterit sulawesi tenggara dalam media asam sulfat. Prosiding Pemaparan Hasil-hasil
Penelitian Pusat Penelitian Geoteknologi LIPI 2014, 527 - 534.

Solihin, S., \& Firdiyono, F., 2018. Perilaku pelarutan logam nikel dan besi dari bijih nikel kadar rendah Sulawesi Tenggara. Metalurgi, 29(2), 139-144. https://doi.org/10.14203/metalurgi.v29i2. 285

Tong, L., Klein, B., Zanin, M., Quast, K., Skinner, W., Addai-Mensah, J., \& Robinson, D., 2013. Stirred milling kinetics of siliceous goethitic nickel laterite for selective comminution. Minerals Engineering, 49, 109-115.

https://doi.org/10.1016/j.mineng.2013.05 .013

Wang, X., 2013. An investigation of the relationship between Western Australian nickel laterites' leaching performance and their mineralogical properties [Thesis, Curtin University]. https://espace.curtin.edu.au/handle/20.50 $0.11937 / 2395$

Zhang, P., Guo, Q., Wei, G., Meng, L., Han, L., Qu, J., \& Qi, T., 2015. Extraction of metals from saprolitic laterite ore through pressure hydrochloric-acid selective leaching. Hydrometallurgy, 157, 149158.

https://doi.org/10.1016/j.hydromet.2015. 08.007 